\title{
Significance of bacteria in the flux of organic matter in the tidal creeks of the mangrove ecosystem of the Indus River delta, Pakistan
}

\author{
Nasreen Bano ${ }^{1, *}$, Mehr-Un Nisa ${ }^{1}$, Nuzhat Khan ${ }^{1}$, Monawwar Saleem ${ }^{1}$, \\ Paul J. Harrison' ${ }^{2}$, Saiyed I. Ahmed ${ }^{3}$, Farooq Azam ${ }^{4}$ \\ 'National Institute of Oceanography, S. T. 47, Block 1, Clifton, Karachi, Pakistan \\ ${ }^{2}$ Department of Earth \& Ocean Sciences, University of British Columbia, Vancouver, British Columbia, Canada V6T IZ4 \\ ${ }^{3}$ School of Oceanography, University of Washington, Seattle, Washington 98195, USA \\ ${ }^{4}$ Scripps Institution of Oceanography, UCSD, La Jolla, California 92093, USA
}

\begin{abstract}
We studied bacterial biomass and production in 3 tidal creeks (Isaro, Gharo and Phitti Creeks) in the mangrove forests in the Indus River delta, Pakistan, to assess the significance of bacteria-mediated carbon fluxes in the creek ecosystem. Bacterial biomass, bacterial carbon production (BCP) and primary productivity (PP) were measured penodically for over a year during 1991-92. BCP was high, generally 50 to $300 \mu \mathrm{g} \mathrm{Cl}^{-1} \mathrm{~d}^{-1}$. Despite such high BCP, bacterial abundance remained between $1 \times 10^{6} \mathrm{ml}^{-1}$ and $4 \times 10^{6} \mathrm{ml}^{-1}$ (20 to $80 \mu \mathrm{g} \mathrm{C}^{-1}$ ) indicating tight coupling between bacterlal production and removal. Specific growth rates generally ranged from 1 to $7 \mathrm{~d}^{-1}$ but the rate reached $24 \mathrm{~d}^{-1}$ during a phytoplankton bloom, apparently a red tide, and this was an unprecedented growth rate for a natural assemblage. The abundance of attached bacteria exhibited a large variation, ranging from 4 to $92 \%$ (mean $35 \pm 21 \%, \mathrm{n}=41$ ) in Isaro Creek and from 14 to $84 \%$ (mean $37 \pm 28 \%, \mathrm{n}=10$ ) in Gharo Creek. Bacterial production due to attached bacteria was 73 to $96 \%$ of the total. Thus, a major fraction of $\mathrm{BCP}$ may have been directly available to metazoan grazers. $\mathrm{BCP}$ was generally much higher than net PP; the yearly integrated average $\mathrm{BCP} / \mathrm{PP}$ for all sites was 2.0. Thus, the growth of bacteria, attached and free, probably represented the major pathway of the production of high quality (low $\mathrm{C}: \mathrm{N}$ ) biomass potentially available to the grazers. Average yearly integrated bacterial carbon demand ( $B C D$ ), estimated conservatively by assuming a $30 \%$ growth efficiency for all sites, was 6.9 times net PP. Thus, the creek water columns were strongly and persistently net heterotrophic. Data integrated over the entire study period show that even if all phytoplankton production was utilized by bacteria it would satisfy only 7 to $20 \%$ of the BCD; the remaining 80 to $93 \%$ of $B C D$ would be met by reduced carbon from other sources. Phytoplankton production was light limited due to high turbidity and, apparently, the majority of $\mathrm{BCP}$ could be supported by the input of mangrove detritus. Estimates of utilizable dissolved organic carbon (UDOC) in selected samples were 97 to $656 \mu \mathrm{g} \mathrm{Cl}^{-1}$, indicating that in order to sustain the measured $\mathrm{BCD}$ $\left(643 \pm 671 \mathrm{~m} \mathrm{C}^{-1} \mathrm{~d}^{-1}\right)$ the UDOC pool would turnover in $<1 \mathrm{~d}$ to a few days. Limited data suggest that bacterial production was carbon rather than $\mathrm{N}$ or $\mathrm{P}$ limited. consistent with sustained high levels of inorganic $\mathrm{N}$ and $\mathrm{P}$ in the surface water. Since mangrove detritus provides most of the energy for bacterial production, which in turn is a significant source of high quality food for grazers, particularly via ingestion of attached bacteria, we predict that the ongoing destruction of mangrove forests in the Indus delta and elsewhere could have a major impact on mangrove ecosystem structure and functioning and the production of economically important fish and shrimp in mangrove creeks.
\end{abstract}

KEY WORDS: Bacteria Organic matter Bacterial production - Mangroves - Tidal creeks · Indus River delta

\section{INTRODUCTION}

We studied the significance of bacterial processes in material and energy fluxes in the tidal creeks of the

\footnotetext{
- Present address: Department of Marine Sciences, University of Georgia, Athens, Georgia 30602-2206, USA.

E-mail: nasreen@uga.cc.uga.edu
}

Indus River delta as part of a multi-disciplinary study (PAKMER; Pakistan Mangrove Ecosystem Research). The Indus delta harbors large mangrove forests areally ranking fifth or sixth in the world. The supply of freshwater to the Indus delta mangroves is quite limited and episodic because these mangroves are in an arid

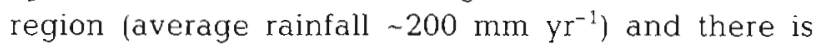
intense demand upstream on river water for agricul- 
tural irrigation (Ahmed 1992b, Harrison et al. 1994) The forests have shrunk drastically over the last several decades and the trees that remain are mainly small statured Avicennia marina restricted to the banks of the better-flushed tidal channels (Snedaker 1984). A substantial fraction ( $27 \%)$ of the forest area consists of tidal creeks and these could contribute significantly to the forest primary production and organic matter decomposition (for an overview of the ecosystem, see Snedaker 1984, Harrison et al. 1994).

Mangroves are amongst the most productive aquatic ecosystems (Mann 1972, Lugo \& Snedaker 1974) and mangrove detritus supports rich fisheries in the creeks and in the adjacent coastal ocean. The material and energy fluxes in the mangrove ecosystems are distinctively shaped by the differences in the digestive capabilities of micro- and macrobiota. Metazoa cannot digest much of the lignocellulose-dominated mangrove detritus for lack of suitable digestive enzymes (Benner \& Hodson 1985). Bacteria and fungi, on the other hand, commonly express ectoenzymes to hydrolyze the detritus to dissolved organic matter (DOM) which they can utilize. Also, leaf leachates and root exudates constitute a large and direct input into the DOM pool (Benner \& Hodson 1985, Benner et al. 1986). Carbon exported from mangroves is important to bacteria (Healey et al 1988). The DOM pool and the DOM-based microbial loop (Azam et al. 1983) may thus be a significant pathway of material and energy flows in the mangrove creek ecosystem. Bacterial biomass being $\mathrm{N}$ and $\mathrm{P}$ rich (bacterial $\mathrm{C}: \mathrm{N}$ is $<4$ and $\mathrm{C}: \mathrm{P}$ is 20; Lee \& Fuhrman 1987, Fagerbakke et al. 1996), their presence would enrich the nutritionally poor mangrove detritus ( $\mathrm{C}: \mathrm{N}=50$ to 80 ) and produce high quality food for metazoa. In addition to phytoplankton production, bacterial growth may be a significant pathway of incorporating dissolved inorganic nitrogen and phosphorus (DIN and DIP) into biomass potentially available to grazers. Therefore, it was of interest to determine the relative production rates of phytoplankton and heterotrophic bacteria in this mangrove ecosystem.

In waters which receive littie allochthonous organic matter input, heterotrophic bacterial production is ultimately limited by the supply of reduced carbon from primary production. The tidal creeks we studied had high turbidity which could limit light penetration and hence primary production (Harrison et al. 1994). Yet, bacterial carbon demand (BCD) need not be limited by the level of phytoplankton productivity because bacteria could use mangrove detritus in addition to phytoplankton production. We therefore hypothesized that $\mathrm{BCD}$ in mangrove creeks would exceed phytoplankton production, thus rendering the creeks net heterotrophic as well as making bacterial production the dominant pathway for the incorporation of $\mathrm{N}$ and $\mathrm{P}$ into the biomass potentially available to protozoa and metazoa. Since free and attached bacteria are expected to have different trophic fates and transfer efficiencies to the higher trophic levels, it was of interest to determine the relative significance of the production of attached and free bacteria. In view of the large detritus load in the creeks, we hypothesized that a major fraction of bacterial biomass and production is particle associated.

There is no previous study addressing our hypotheses in the Indus delta mangrove ecosystem. Extensive studies of this nature have been done in Australian mangroves but these were mainly concerned with benthic microbial processes (Alongi 1988, 1992, Boto et al. 1989).

In order to test our hypotheses, we estimated the biomass and production rates of bacteria and phytoplankton in 3 tidal creeks and attempted to distinguish between the biomass and production rates of attached and free bacteria. We examined spatial variation in bacterial biomass and production during 2 transects in Isaro Creek. The scope of our study was limited to obtaining time series data to establish carbon budgets (and inferred nitrogen budgets) and did not evaluate the cause of variability in pools and rates, although some observations in this respect are noted. A companion paper (Harrison et al. 1997) considered the nutrient and phytoplankton dynamics at the same study sites.

\section{MATERIAL AND METHODS}

Study sites. The study area is located in a mangrove swamp in the western part of the Indus River delta. The sampling stations are in 3 inter-connected tidal creeks: Isaro Creek is connected with Gharo Creek which is connected with Phitti Creek which in turn opens into the Arabian Sea (Fig. 1). Logistic constraints restricted most sampling to Isaro and Gharo Creeks. Between January 1991 and January 1992 we sampled Isaro Creek 16 times and Gharo Creek 7 times. Phitti Creek was sampled only once. Two stations were selected in Isaro Creek, Isaro Main (IM) in the broader part of the creek and Isaro Branch (IB) in a small, narrow branch of the creek. Sampling in Gharo Creek was also done at 2 stations, one in the wide part of Gharo Creek called Gharo Main (GM) and the other in a side branch called Gharo Branch (GB).

Isaro and Gharo Creeks are both 3 to $9 \mathrm{~m}$ deep and 100 to $400 \mathrm{~m}$ wide. Salinity remained above $38 \%$ during the dry season but dropped to $32-35 \%$ during the rainy season (July-August). Current velocity (based on 2 current meter measurements) was $0.52 \mathrm{~m} \mathrm{~s}^{-1}$ during the spring tide and $0.26 \mathrm{~m} \mathrm{~s}^{-1}$ during the neap tide. 


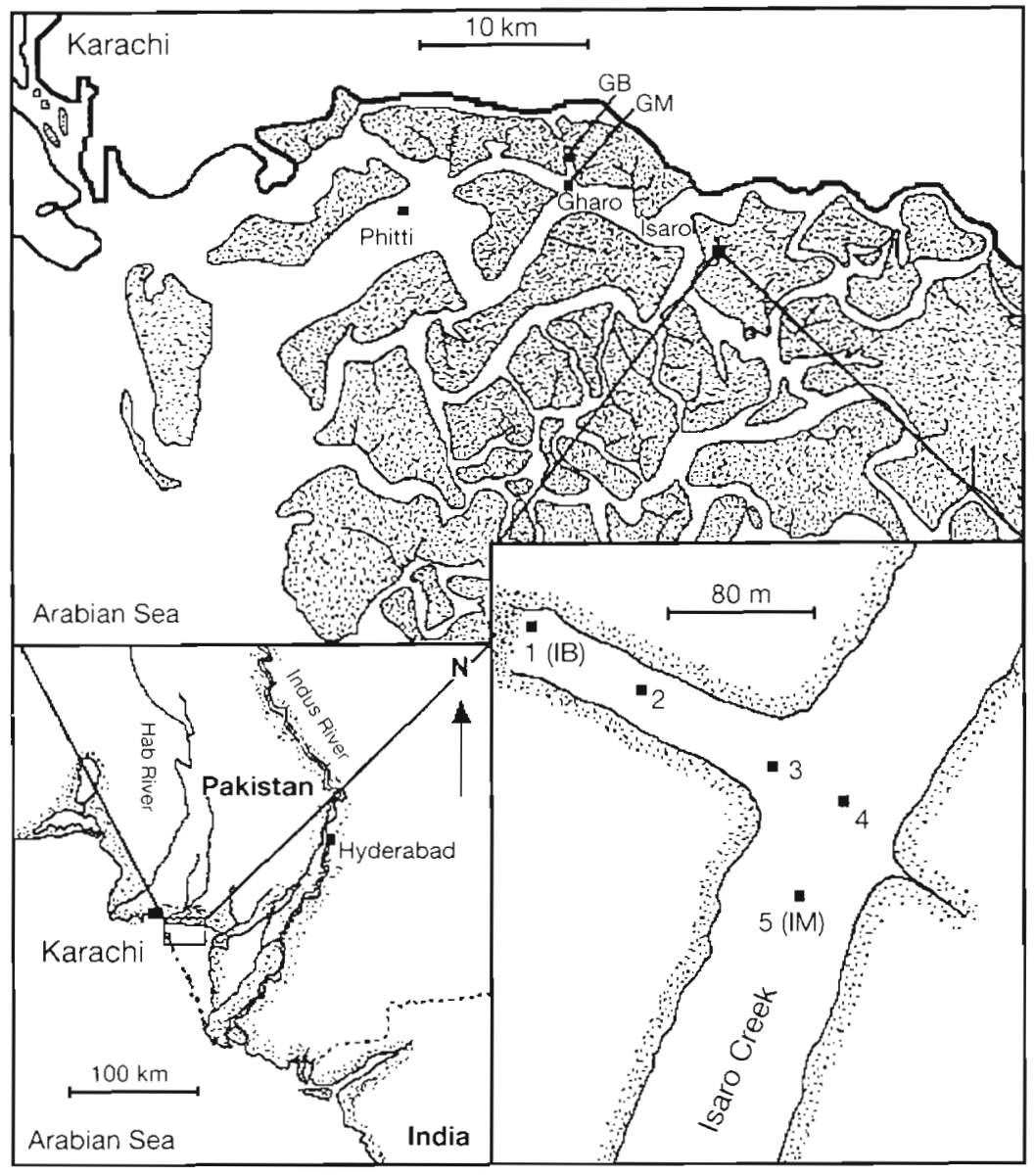

Fig. 1 Study area showing approximate position of sampling sites ( $\boldsymbol{\square}$ ) in 3 tidal creeks, Isaro (IM: Isaro Main; IB: Isaro Branch), Gharo (GM: Gharo Main; GB Gharo Branch) and Phitti Creeks, in the western part of the Indus River delta Pakistan

Water movement during a $6 \mathrm{~h}$ flood or ebb spring tide was 5 to $11 \mathrm{~km}$. Phitti Creek is the deepest of the 3 creeks, 8 to $20 \mathrm{~m}$, with a salinity range of 33 to $38 \%$. This creek flushes completely with seawater. Current velocities were $>1 \mathrm{~m} \mathrm{~s}^{-1}$ during the ebb tide and $<1 \mathrm{~m}$ $\mathrm{s}^{-1}$ during the flood. All 3 creeks are lined by mangrove stands. IB is narrow and without an outlet; it is surrounded on 3 sides by mangrove stands and was likely to be most influenced by the input of mangrove exudates and detritus. The dominant species of mangrove at all study sites was Avicennia marina which is reportedly the most salt tolerant and, hence, this species has survived despite seasonally high salinities, up to $70 \%$ in summer, caused by the reduction in the flow of the Indus River into the estuary (Ahmed 1992a).

Sampling. Surface water samples were taken with an acid-washed insulated plastic container and bottom water samples were taken with a 51 Niskin sampler. Temperature and oxygen profiles were determined with a YSI oxygen meter.
Bacterial abundance. Bacterial abundance was determined by the acridine orange direct count method (Hobbie et al. 1977). Surface and bottom water samples $(10 \mathrm{ml})$ were fixed with borate-buffered $0.2 \mu \mathrm{m}$ filtered formalin at $2 \%$ final concentration and stored refrigerated until processing. Within a few days of collection 2 to $5 \mathrm{ml}$ subsamples were stained with $0.01 \%$ final concentration acridine orange for $3 \mathrm{~min}$ and then filtered onto $0.2 \mu \mathrm{m}$ pore-size blackened Nuclepore polycarbonate membrane filters. Bacteria were counted by epifluorescence microscopy in 10 randomly selected fields. Attached bacteria were also estimated by counting 10 random fields in the same slide (Ducklow et al. 1985). A sonicator was not available, and therefore we could not dislodge the attached bacteria from particles. In order to roughly account for bacteria under the particles, we doubled our counts of the attached bacteria (Bent \& Goulder 1981). Bacterial carbon was calculated from bacterial abundance by assuming a per cell carbon content of $20 \mathrm{fg}$ (Lee \& Fuhrman 1987).

Bacterial carbon production (BCP). Bacterial production was estimated from rates of ${ }^{14} \mathrm{C}$-leucine (Leu) incorporation into the protein fraction (Kirchman et al. 1985, Simon \& Azam 1989). During the later part of the study (July 1991 to January 1992) a modified procedure (Smith \& Azam 1992) was used because it was more economical and convenient. Surface and bottom water samples $(1.5 \mathrm{ml})$ were incubated with $54 \mathrm{nM}$ (final conc.) of ${ }^{14} \mathrm{C}(\mathrm{U})$-Leu in $2 \mathrm{ml}$ Eppendorf tubes at in situ temperatures in the dark. All measurements were done in triplicate together with 1 blank. Blanks received 5\% (final conc.) trichloroacetic acid (TCA) before adding Leu. Samples were incubated for known periods of time, always $\sim 30$ min, followed by the addition of TCA at $5 \%$ and bovine serum albumin (BSA) at $0.03 \%(w / v)$. Samples were centrifuged in a microcentrifuge at $16000 \times g$ for 10 min. The supernatant was aspirated off and the pellet washed twice with 5\% TCA. Liquid scintillation cocktail (1 ml) (Packard Opti-fluor) was added to each tube, and the tubes were placed in reusable scintillation vials and radioassayed in a liquid scintillation spectrometer. Bacterial protein production and bacterial carbon production were calculated according to Simon 
\& Azam (1989) assuming 2-fold isotope dilution. The method of Smith \& Azam (1992) was compared with the filtration-based procedure with 3 water samples taken at each of IM and GM. Bacterial carbon production by the 2 methods gave the relationship ( $\pm 1 \mathrm{SD}$ ): centrifugation/filtration $=1.17 \pm 0.17(n=6)$.

Concentration-dependence of leucine incorporation. Leu incorporation was measured at a range of added concentrations in Isaro Creek in July 1991 We wanted to determine the leucine pool turnover time (Azam \& Hodson 1981) as well as $K_{\mathrm{m}}+S_{\mathrm{n}}$ and $V_{\max }$ (Wright \& Hobbie 1965). We added 8 to 130 nM Leu to determine the concentration which would maximize the participation of exogenous leucine in protein synthesis (to minimize isotope dilution; Simon \& Azam 1989). In order to estimate the kinetic parameters $V_{\max }$ $t / f$ and $K_{\mathrm{m}}+S_{\mathrm{n}}$, the incorporation data was plotted as $[A]$ versus $t / f$, where $[A]$ is the concentration of leu added, and $f$ is the fraction of the added label incorporated in time $t$.

Bacterial carbon demand (BCD). This was calculated on the basis of BCP by assuming a carbon assimilation efficiency of $30 \%$ (Bjørnsen \& Kuparinen 1991) but a range of 10 to $30 \%$ was used in some cases (see 'Discussion')

BCP of attached and free bacteria. During 2 transects, on September 18 and December 2, 1991, subsamples were filtered through $0.6 \mu \mathrm{m}$ Nuclepore filters and the bacteria passing the filters were considered free. Filtrates and unfiltered subsamples were incubated with Leu to measure BCP, as above. BCP in the $>0.6 \mu \mathrm{m}$ fraction was calculated as the difference between the BCP of total and $0.6 \mu$ m filtered samples.

Specific growth rate. The assemblage-average bacterial specific growth rate $(\mu)$ was calculated as: $\mu=$ $\left[\ln \left(B_{0}+P\right)-\ln B_{0}\right] / T$, where $B_{0}$ was initial bacterial carbon, $P$ was bacterial carbon production and $T$ was incubation time for the ${ }^{14} \mathrm{C}$-leucine incorporation assay.

Utilizable dissolved organic carbon (UDOC). This was measured essentially by the bacterial carbon yield method of Ammerman et al. (1984). Briefly, creek surface water samples were filtered through $0.6 \mathrm{fm}$ Nuclepore filters to eliminate or reduce the abundance of bacterivorous protozoa and $50 \mathrm{mI}$ of the filtrate was incubated at $25 \pm 5^{\circ} \mathrm{C}$ for 1 to $4 \mathrm{~d}$. Bacteria in the filtrate were counted at the beginning $\left(T_{0}\right)$ and periodically during the incubation. The yield of bacteria was calculated as the difference between the maximum cell count during the incubation and that at $T_{0}$. Samples which became contaminated with protozoa were discarded.

Chlorophyll a (chl a) and primary production (PP). Chl a was measured spectrophotometrically in samples collected on GF/F filters and extracted with $90 \%$ ace- tone (Parsons et al. 1984). PP was measured by the ${ }^{14} \mathrm{C}$ method (Steemann Nielsen 1952, Parsons et al. 1984) and described by Harrison et al. (1997). Areally integrated values for the entire water column were calculated for comparison with areally integrated $\mathrm{BCP}$ and BCD.

\section{RESULTS}

Physicochemical parameters. Water temperature ranged from 28 to $34^{\circ} \mathrm{C}$ in summer and 20 to $22^{\circ} \mathrm{C}$ in winter (Fig. 2). Oxygen concentration ranged from 5.6 to $7.0 \mathrm{mg} \mathrm{i}^{-1}$ and salinity ranged from 37 to $41 \%$ in Isaro Creek and 36 to $43 \%$ in Gharo Creek during our sampling (not shown). In most cases there was no difference in surface and near-bottom temperature, salinity and dissolved oxygen concentration, indicating that the water column was well mixed.

Bacterial abundance, $\mathrm{chl} \mathrm{a}$ and carbon pools. Generally, bacterial abundance ranged from 1 to $4 \times$ $10^{6} \mathrm{ml}^{-1}$ in Isaro Creek (mean $2.7 \pm 1.6 \times 10^{6} \mathrm{ml}^{-1}, \mathrm{n}=$ 60; Fig. 3A) and 1 to $3 \times 10^{6} \mathrm{ml}^{-1}$ in Gharo creek (mean $2.1 \pm 0.7 \times 10^{6} \mathrm{ml}^{-1}, \mathrm{n}=21$; Fig. 4A). Bacterial abundances in the surface and the near-bottom water samples were quite similar, which indicates that the water columns were well mixed. Chl a ranged from 1 to $8 \mu \mathrm{g}$ $\mathrm{l}^{-1}$ (mean $3.6 \pm 2.6 \mu \mathrm{g} \mathrm{l}^{-1}, \mathrm{n}=57$ ) in Isaro Creek (Fig. 3B), except during phytoplankton blooms on February 13 and June 5, 1991 (18 and $41 \mathrm{\mu g} \mathrm{l}^{-1}$, respectively). Chl $a$ in Gharo Creek ranged from 1 to $3.5 \mu \mathrm{g}$ $\mathrm{l}^{-1}$ (mean $2.5 \pm 1 \mu \mathrm{g} \mathrm{l}^{-1}, \mathrm{n}=17$; Fig. 4B) and values in the surface and the near-bottom samples were also similar in most cases. The ratio of bacterial carbon to phytoplankton carbon $\left(\mathrm{C}_{b} / \mathrm{C}_{\mathrm{p}}\right.$; not shown) generally ranged from 0.1 to 0.5 . In IM, on February 13, bacterial abundance was very low, 0.3 to $0.4 \times 10^{6} \mathrm{ml}^{-1}$ (Fig. $3 \mathrm{~A}$ ). For comparison, these abundances are in the lower part of the range of bacterial abundances in the oligotrophic waters of the North Pacific central gyre (Cho \& Azam 1990). Interestingly, the low counts occurred

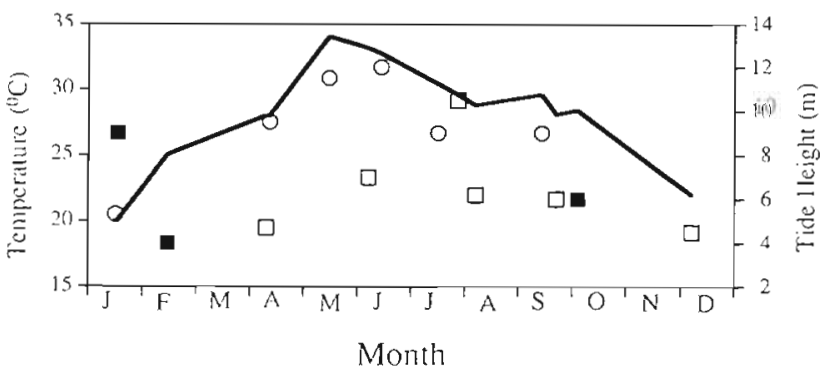

Fig. 2. Surface water temperature (solid line) and tidal height at sampling time in Isaro Creek during 1991. (O) Spring tide; (ㄷ) neap tide; ( $\mathbf{\square}$ ) between spring and neap tide 
during a phytoplankton bloom, apparently a red tide, with surface chl $a$ of $18 \mu \mathrm{g} \mathrm{I}^{-1}$ (Fig. 3B) and at a time when bacterial production (255 $\mu \mathrm{g} \mathrm{C} \mathrm{l}^{-1} \mathrm{~d}^{-1}$; Fig. 3C) and $\mu\left(24 \mathrm{~d}^{-1}\right.$; Fig. 3D) were very high. Thus, there must have been highly efficient removal of bacterial biomass possibly through intensive grazing and/or phage-induced lysis (not measured).

Bacterial production. $\mathrm{BCP}$ at all 4 stations varied more than an order of magnitude. The rates generally

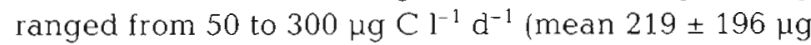
$\mathrm{l}^{-1} \mathrm{~d}^{-1}, \mathrm{n}=54$; Fig. 3C) in Isaro Creek and 50 to $150 \mu \mathrm{g}$ $\mathrm{l}^{-1} \mathrm{~d}^{-1}$ in Gharo Creek (mean $102 \pm 46 \mu \mathrm{g} \mathrm{l}^{-1} \mathrm{~d}^{-1}, \mathrm{n}=20$; Fig. $4 \mathrm{C}$ ). The values were somew hat higher in IB than in IM. Concurrent peaks, on June 5, occurred in IB and IM with BCP values of 664 and $900 \mu \mathrm{g} \mathrm{l}^{-1} \mathrm{~d}^{-1}$. Bacterial abundance and production rate are comparable to

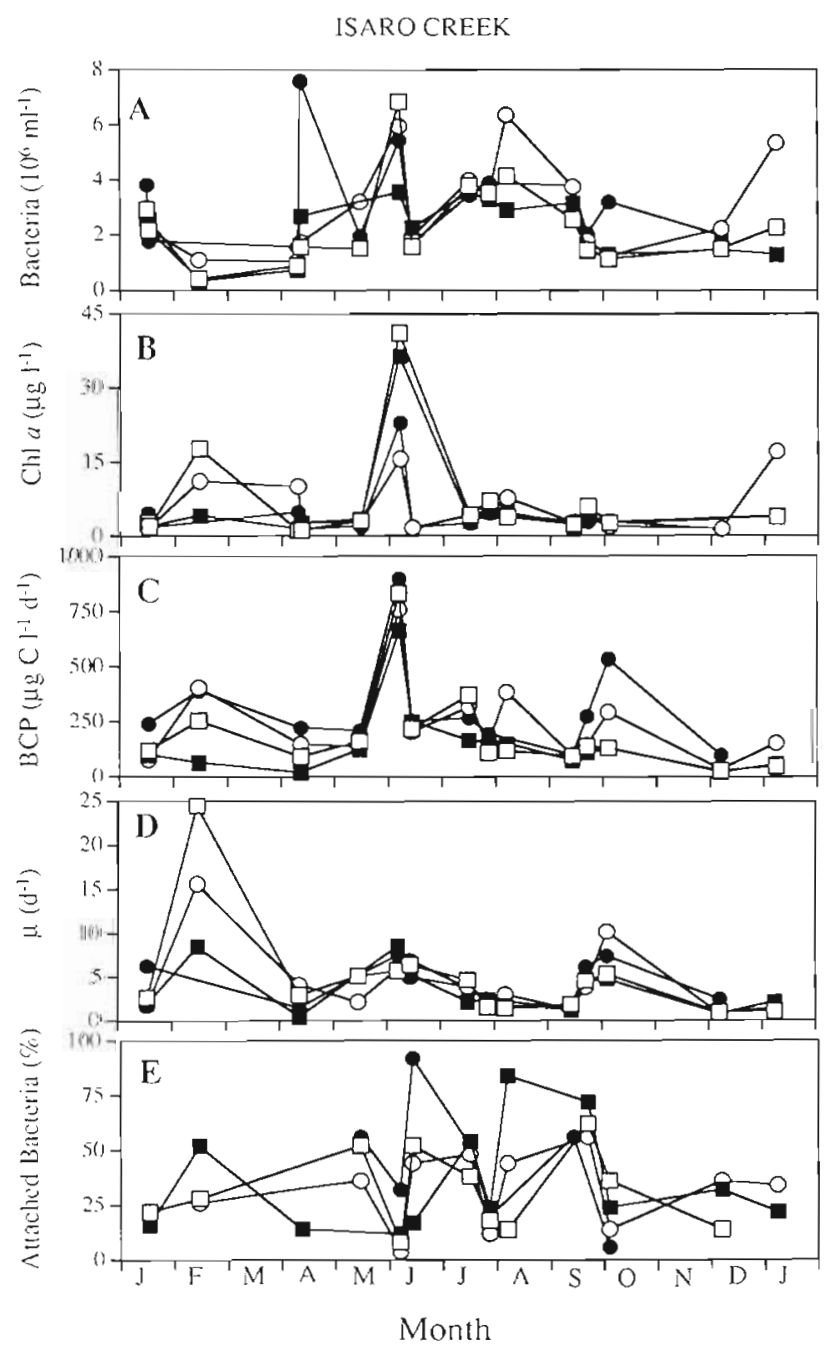

Fig. 3. Measured variables in Isaro Main (IM) surface ( $\square$ ) and bottom ( $\square$ ) and Isaro Branch (IB) surface (O) and bottom (O) from January 1991 to January 1992. BCP: bacterial carbon production
GHARO CREEK
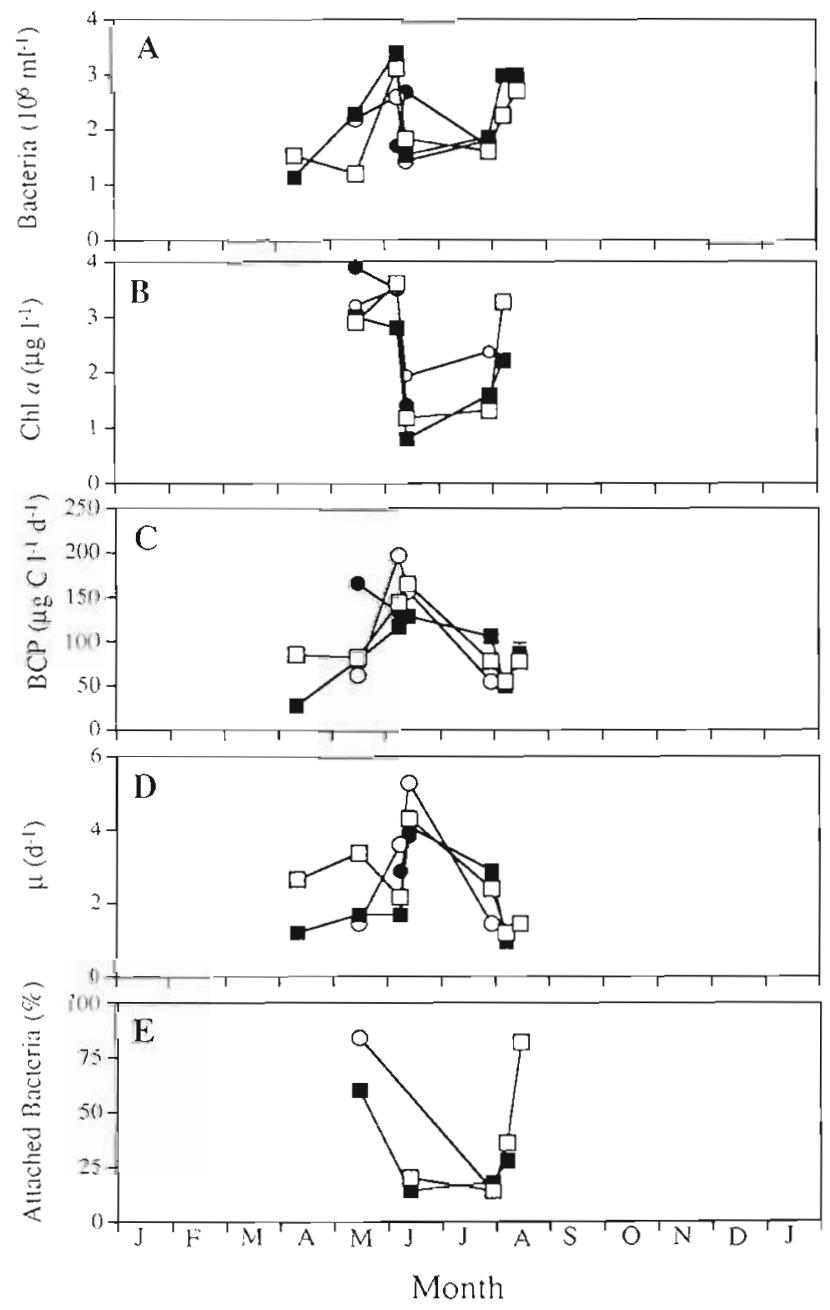

Fig. 4. Measured variables in Gharo Main (GM) surface ( $\square$ ) and bottom ( $)$ and Gharo Branch (GB) surface (O) and bottom (1rom April 1991 to August 1991

those in the Hudson River estuary, USA, a strongly heterotrophic ecosystem (Findlay et al. 1991)

Specific growth rates. Specific growth rates $(\mu)$ in both Isaro and Gharo Creeks were very high. In Isaro Creek the assemblage-averaged specific growth rates generally ranged from 2 to $7 \mathrm{~d}^{-1}$ (Fig. 3D). Peaks in $\mu$ occurred both in IM and IB at the time of a phytoplankton bloom, on February 13, when the values of $\mu$ were $24 \mathrm{~d}^{-1}$ (IM) and $15.6 \mathrm{~d}^{-1}$ (IB). As stated above, these peaks coincided with low bacterial abundances. During a second and larger phytoplankton bloom, on June 5, both bacterial abundance and production were the highest measured in this study and $\mu$ was $\sim 7 \mathrm{~d}^{-1}$. Thus, in contrast to the first bloom, this bloom was accompanied by a large population of rapidly growing bacteria (although not as rapidly as during the first bloom). In Gharo Creek, no major phytoplankton 


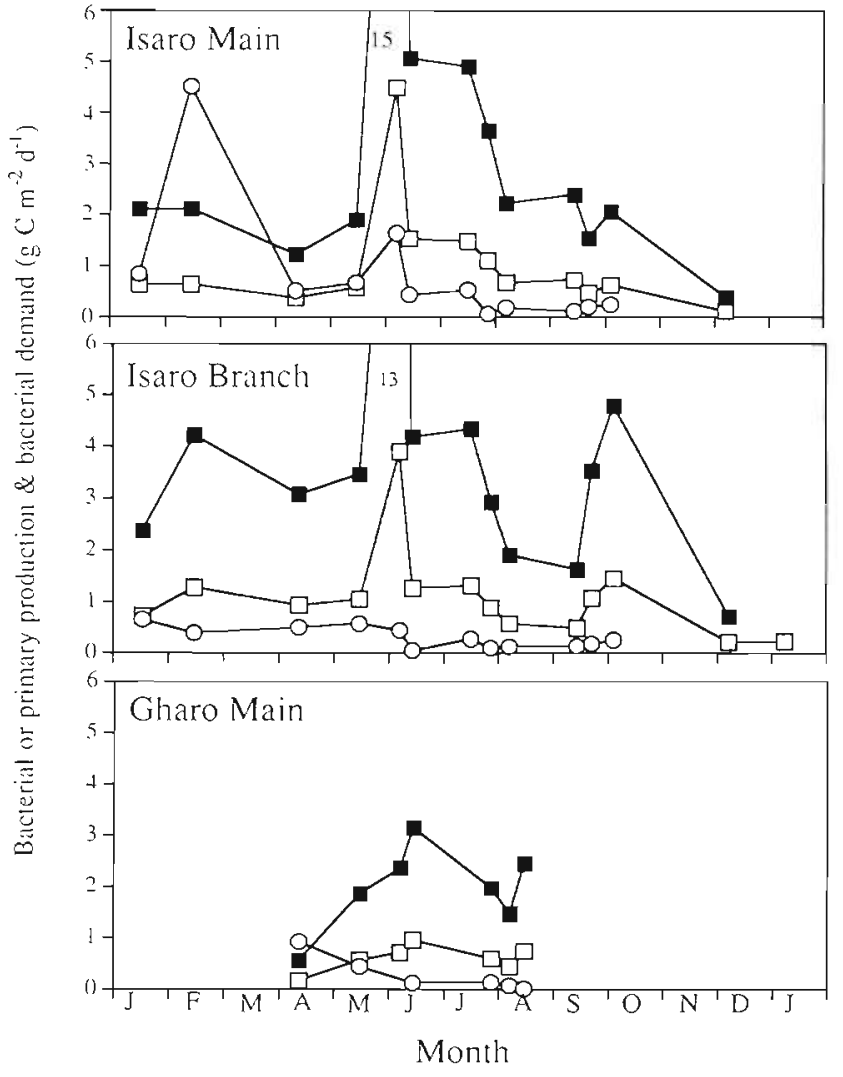

Fig. 5. Depth-integrated primary production (0), bacterial production ( $\square$ ) and bacterial carbon demand assuming $30 \%$ growth efficiency ( $\square$ ) at IM, IB and GM stations

blooms were recorded (chl a was $\sim 1$ to $3.5 \mu \mathrm{g} \mathrm{l}^{-1}$ ) nor any large increases in $\mu$, which generally ranged from 1 to $3 \mathrm{~d}^{-1}$ (Fig. 4D). Bacterial assemblages in Phitti Creek, sampled only once, showed modest $\mu$ of 0.4 to $1.6 \mathrm{~d}^{-1}$.

Attached bacteria. Attached bacteria were highly variable during different sampling periods (Figs. 3E \& $4 \mathrm{E})$; at times they became dominant, ranging from 4 to
$92 \%$ (mean $35 \pm 21 \%, n=41$ ) in Isaro Creek and 14 to $84 \%$ (mean $37 \pm 28 \%, \mathrm{n}=10$ ) in Gharo Creek. There was no clear seasonal pattern.

Primary production. This was measured regularly in Isaro and Gharo Creeks and once in Phitti Creek. The detailed data are presented by Harrison et al. (1997). Except for 2 peaks of 4.5 and $1.65 \mathrm{~g} \mathrm{C} \mathrm{m}^{-2} \mathrm{~d}^{-1}$ on Feb-

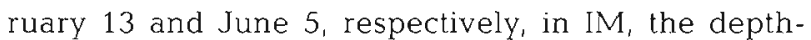
integrated values in IM and IB ranged from 0.1 to $0.8 \mathrm{~g} \mathrm{C} \mathrm{m}^{-2} \mathrm{~d}^{-1}$ (Fig. 5). The IB station showed much less pronounced peaks in PP than IM. At GM, PP ranged from 0.005 to $0.9 \mathrm{~g} \mathrm{C} \mathrm{m}^{-2} \mathrm{~d}^{-1}$. PP was limited by light penetration (Harrison et al. 1994) at all stations at all times.

Relationship of PP with BCP and BCD. In most samples BCP was greater than net PP (Fig. 5). Yearly integrated BCP/PP averaged for all sites except Phitti Creek was 2.0 (Table 1). BCD calculated by assuming a carbon assimilation efficiency of 10 or $30 \%$ was compared with $\mathrm{PP}$ to estimate $\mathrm{BCD} / \mathrm{PP}$ (Table 1 ); this ratio for the entire data set (except Phitti Creek) ranged from 2.3 to 9.4 (assuming 30\% growth efficiency), or 6.9 to 28.2 (assuming 10\% growth efficiency).

Time-course of leucine incorporation. Whether the time course was linear during our $\sim 0.5 \mathrm{~h}$ incubations was determined on 1 occasion in IM and IB. The uptake of leucine incorporation was linear for at least $1.2 \mathrm{~h}$ (Fig. 6A).

Concentration-dependence of leucine incorporation. Simon \& Azam (1989) recommended $20 \mathrm{nM}$ Leu addition for marine samples, since they found that label incorporation into protein was maximum at or below that concentration. We considered that in eutrophic waters in this study, higher leucine additions may be necessary (Riemann \& Azam 1992). In our routine sampling, we had arbitrarily chosen to add $54 \mathrm{nM}$ leucine and we wanted to test whether the label incorporation rates at $54 \mathrm{nM}$ approached $V_{\max }$. In all our samples, label incorporation was submaximal at $20 \mathrm{nM}$, but $V_{\max }$ was approached at 30 to $57 \mathrm{nM}$. The

Table 1. Integrated yearly bacterial carbon production (BCP), bacterial carbon demand (BCD, assuming $\mathrm{C}$ assimilation efficiency range of 30 to $10 \%$ ), primary production (PP), bacterial $\mathrm{N}$ production/phyto. N production (assuming bacterial $\mathrm{C}: \mathrm{N}=4$ and phytoplankton $\mathrm{C}: \mathrm{N}=7$ ) and bacterial $\mathrm{C}$ respiration/PP. Data from Phitti Creek are not included in average

\begin{tabular}{|lccccccc|}
\hline Location & $\begin{array}{c}\mathrm{BCP} \\
\left(\mathrm{g} \mathrm{C} \mathrm{m}^{-2} \mathrm{yr}^{-1}\right)\end{array}$ & $\begin{array}{c}\mathrm{BCD}(30-10 \%) \\
\left(\mathrm{g} \mathrm{C} \mathrm{m}^{-2} \mathrm{yr}^{-1}\right)\end{array}$ & $\begin{array}{c}\mathrm{PP} \\
\left(\mathrm{g} \mathrm{C} \mathrm{m}^{-2} \mathrm{y}^{-1}\right)\end{array}$ & BCP/PP & BCD/PP & $\begin{array}{c}\text { Bact. N prod./ } \\
\text { phyto. N prod. }\end{array}$ & Bact. C resp./PP \\
\hline Isaro Main & 293 & $977-2930$ & 425 & 0.7 & $2.3-6.9$ & 1.2 & $1.6-6.2$ \\
Isaro Branch & 355 & $1183-3550$ & 126 & 2.8 & $9.4-28.2$ & 4.9 & $6.6-25.4$ \\
Gharo Main & 225 & $750-2250$ & 111 & 2.0 & $6.8-20.3$ & 3.5 & $4.7-18.3$ \\
Gharo Branch & 116 & $387-1160$ & 42 & 2.8 & $9.2-27.6$ & 4.8 & $6.4-24.9$ \\
Phitti (only 1 & 204 & $680-2040$ & 7.5 & 27 & $90-272$ & 40.6 & $64-245$ \\
$\quad \begin{array}{c}\text { sampling) } \\
\text { Average }\end{array}$ & 247 & $824-2470$ & 176 & 2.0 & $6.9-20.8$ & 3.6 & $4.8-18.7$ \\
\hline
\end{tabular}



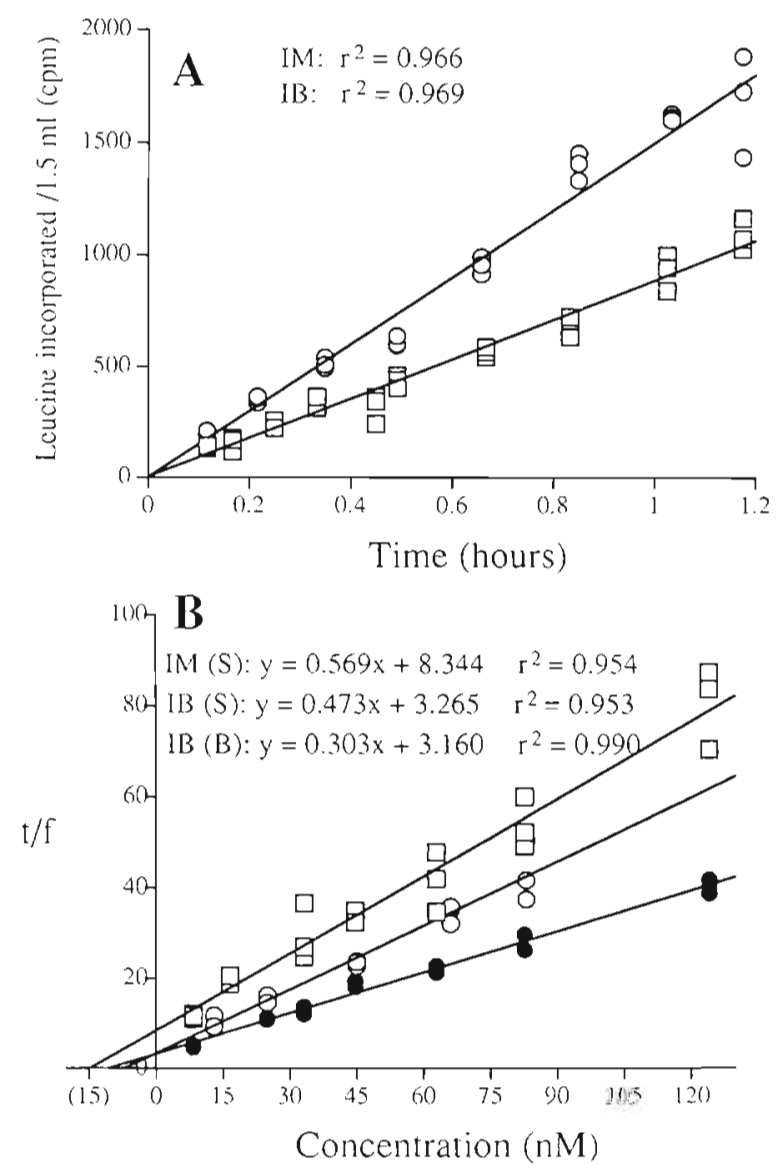

Fig. 6. (A) Incorporation of ${ }^{14} \mathrm{C}$-leucine as a function of time in waters of IM ( $\square$ ) and IB (O); (B) Wright-Hobbie plots for bacterial uptake of ${ }^{14} \mathrm{C}$-leucine in IM surface $(\square)$, IB surface (O) and IB bottom ( ) $f$ : fraction of the added label incorporated in time $t$

uptake data showed an excellent fit to the WrightHobbie formulation $\left(\mathrm{r}^{2}=0.95\right.$ to 0.99 ; Fig. $\left.6 \mathrm{~B}\right)$ without any evidence of multiphasic kinetic patterns in the concentration range used (Azam \& Hodson 1981). Whether other low $K_{\mathrm{m}}$ and high $V_{\max }$ uptake systems existed in the population cannot be determined because we used a relatively narrow range of concentration. $V_{\max }$ was determined from the kinetic plots and ranged from 1.5 to $2.8 \mathrm{nmol} \mathrm{l}^{-1} \mathrm{~h}^{-1}$, equivalent to $\mathrm{BCP}$ rates of 112 to $208 \mu \mathrm{g} \mathrm{Cl}^{-1} \mathrm{~d}^{-1}$. Leucine pool turnover rates were rapid. The $K_{m}+S_{n}$ values, and hence the maximum estimates of $S_{\mathrm{n}}$, were only 8 to $15 \mathrm{nM}$. Thus, the leucine pool was highly dynamic and was kept at a low level by rapid utilization by bacteria and possibly fungi as well.

Utilizable DOC. Bacterial growth was followed in seawater batch cultures on 3 sampling dates (Table 2) to determine bacterial yield supportable by $0.6 \mu \mathrm{m}$ filtered seawater and thus the pool of dissolved utilizable organic matter. Bacterial yield ranged from 1.5 to $9.9 \times$
$10^{-6} \mathrm{ml}^{-1}$, which corresponds to a BCD range of 97 to $656 \mu \mathrm{C} \mathrm{Cl}^{-1}$ (assuming 30\% growth efficiency). We found that sometimes even in those samples which showed no protozoan contamination, bacterial counts decreased after the initial increase. This decline could be due to phage attack or mortality due to nutrient stress. Bacterial mortality could have caused an underestimation of UDOC estimates. Our estimates of UDOC are therefore conservative, because we assumed a high growth yjeld and because of possible underestimation of BCD due to bacterial mortality.

Isaro transect. Two transects on September 18 and December 2, 1991, were made in Isaro Creek to examine the mesoscale variability $(0.1$ to a few $\mathrm{km}$ ) of bacterial parameters. Stns 1 and 2 were surrounded on 3 sides by mangrove stands and Stns 3 to 5 were in the broader portion of the main creek (Fig. 1). Stns 1 and 5 were the same as IB and IM stations, respectively, in the seasonal sampling. During the transect, bacterial abundance ranged from 1.4 to $2.6 \times 10^{-6} \mathrm{ml}^{-1}$ (Fig. 7A) and showed a general decrease from Stn 1 to Stn 5 . During this transect, $\mu$ for the bacterial assemblages was much higher during September ( 4 to $6 \mathrm{~d}^{-1}$ ) than in December (generally 1 to $2 \mathrm{~d}^{-1}$; Fig. $7 \mathrm{C}$ ) . Depth-integrated bacterial production was high at all stations compared to primary production (Fig. 7E). The ratio of $\mathrm{BCD} / \mathrm{PP}$ ranged from 8 to 18 . The highest $\mathrm{BCD} / \mathrm{PP}$ ratio was at IB (Stn 1) and this ratio showed a general decrease along the transect. Attached bacteria $(>0.6 \mu \mathrm{m})$ for all 5 stations in both transects ranged from 32 to $74 \%$ (mean $53 \pm 11 \%$; Fig. $8 \mathrm{~A}$ ). By the difference between the total and $0.6 \mu \mathrm{m}$-filtered leucine incorporation measurements, 73 to $96 \%$ (mean $87 \pm$ $11 \%$ ) leucine incorporation was by the fraction which was retained by the $0.6 \mu \mathrm{m}$ Nuclepore filter (Fig. 8B). Production due to free bacteria was a minor fraction (4 to $27 \%$, mean $12 \pm 10 \%$ ) of the total. Specific growth rate of $>0.6 \mu \mathrm{m}$ bacteria ranged from 6 to 10 and 1.9 to

Table 2. Yield of bacteria and utilizable dissolved organic matter (UDOM, calculated from bacterial yield assuming $30 \%$ carbon assimilation efficiency) with $\pm 1 \mathrm{SD}$ ( $\mathrm{n}=3$ where $\mathrm{SD}$ is given) in $0.6 \mu \mathrm{m}$ filtered surface water from Isaro Creek

\begin{tabular}{|cccc|}
\hline Stn & $\begin{array}{c}\text { Sampling } \\
\text { date }\end{array}$ & $\begin{array}{c}\text { Yield of } \\
\text { bacteria } \\
\left(10^{9} \mathrm{l}^{-1}\right)\end{array}$ & $\begin{array}{c}\text { UDOM } \\
\left.(\mu \mathrm{g} \mathrm{C})^{-1}\right)\end{array}$ \\
\hline 1 & Mar 1990 & 8.8 & 578 \\
3 & Mar 1990 & 4.4 & 290 \\
5 & Jul 1991 & $9.9 \pm 0.1$ & $656 \pm 5$ \\
1 & Sep 1991 & $4.2 \pm 0.6$ & $278 \pm 41$ \\
2 & Sep 1991 & $3.0 \pm 0.8$ & $196 \pm 52$ \\
3 & Sep 1991 & 2.3 & 152 \\
4 & Sep 1991 & $1.5 \pm 0.3$ & $97 \pm 18$ \\
5 & Sep 1991 & 3.6 & 240 \\
\hline
\end{tabular}




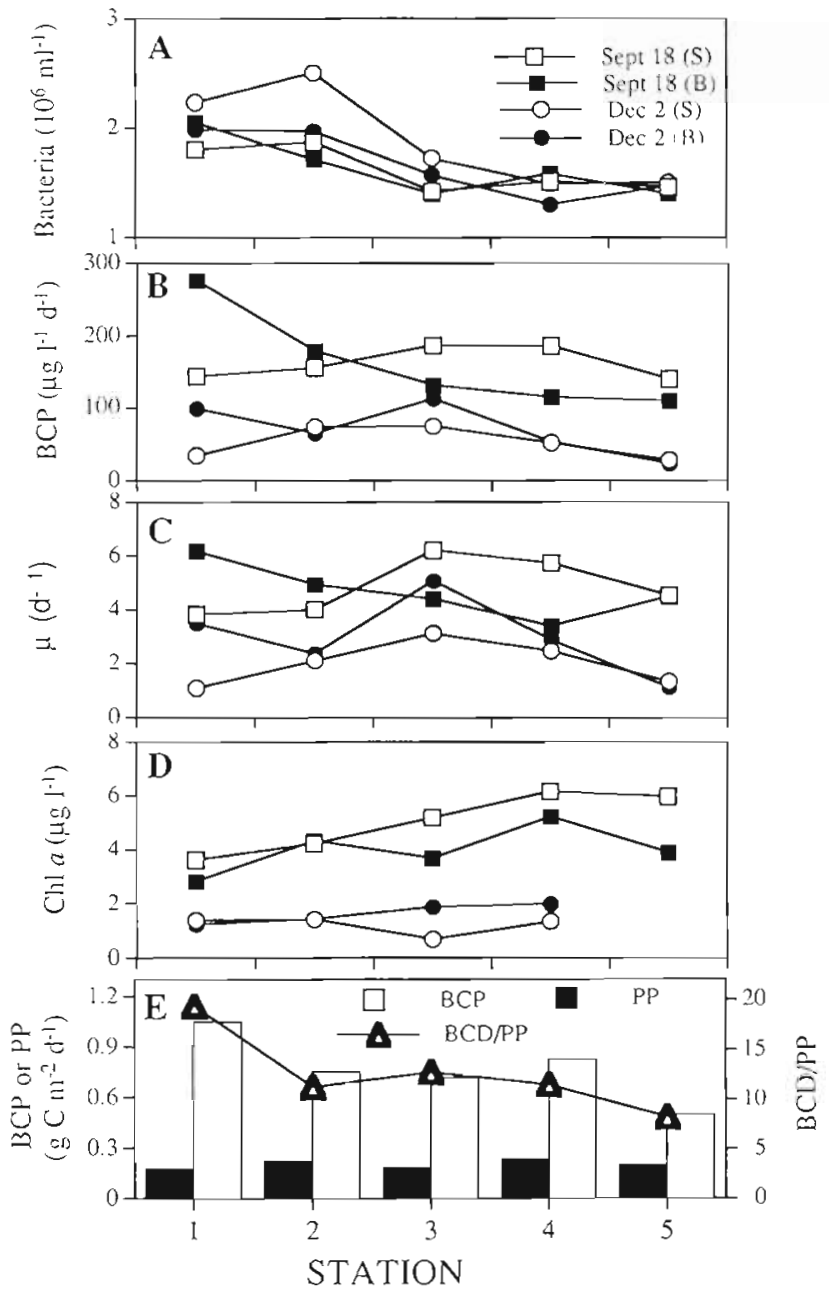

Fig. 7. (A) Bacterial abundance, (B) bacterial carbon production (BCP), (C) specific growth rate and (D) chl a during 2 transects on September 18 and December 2, 1991, in Isaro Creek and $(E)$ depth-integrated $B C P$, phytoplankton production (PP) and bacterial carbon demand/PP (BCD/PP), measured only on September 18, 1991

$8 \mathrm{~d}^{-1}$ in the September 18 and December 12 transects, respectively (Fig. 8B). Production due to attached bacteria may have been overestimated to an unknown extent because some free bacteria may have been retained by the $0.6 \mu \mathrm{m}$ Nuclepore filter (we would probably have reduced the overestimation by using $1 \mu \mathrm{m}$ Nuclepore filters, but we did not have these available to us at that time).

\section{DISCUSSION}

\section{Food web significance of bacterial production}

In view of the low nutritional quality of the mangrove detritus, the production of phytoplankton and bacterial biomasses probably represented the main pathways for the synthesis of high quality (low $\mathrm{C}: \mathrm{N}$ ) biomass potentially available to the grazers in the mangrove creek ecosystem. It is noteworthy, then, that BCP was generally substantially higher than net PP (average $\mathrm{BCP} / \mathrm{PP}$ was 2.0 ; Table 1). Since the $\mathrm{C}: \mathrm{N}$ ratio of bacteria is -4 (Lee \& Fuhrman 1987) and that of phytoplankton is 6 to 7 (Harris 1986) the bacteria:phytoplankton $N$ production ratio would be even higher than the $\mathrm{C}$ production ratio. Thus, bacterial production may be an important pathway of the synthesis of high quality biomass in our study area.

We did not study the trophic fate of bacteriai production. Heterotrophic microflagellates were present at $10^{3}$ to $10^{4} \mathrm{ml}^{-1}$, abundances which are typical of coastal ocean surface waters. However, we did not measure their grazing on bacteria. Viruses could have lysed some of the bacterial production. We counted viruses, by transmission electron microscopy, in 2 samples from Isaro Creek in January 1992 and found abundances on the order of $3 \times 10^{6} \mathrm{ml}^{-1}$ (these may be underestimates since some viruses may have gone unnoticed by being adsorbed on particles); however, the rate of phageinduced mortality of bacteria was not determined. Ingestion of attached bacteria is a potentially important pathway for the transfer of bacterial production to the higher trophic levels. The percentage of attached bacteria (Figs. 3E \& 4E) in the seasonal study was highly variable, ranging from 4 to $92 \%$ in Isaro Creek. In the 2 Isaro Creek transects, discussed earlier, the abundance of attached bacteria was 32 to $74 \%$ and their production was 73 to $96 \%$ of the total (Fig. 8 ; but these may be overestimates, as discussed). Depending on the size of the particles to which bacteria were attached, this bacterial production could be directly available to a variety of detritivores (Lawrence et al. 1993. Crump \& Baross 1996). Such transfer of bacterial production to the higher trophic levels is probably quite important because of the direct nature of the transfer. Further, the high variability in percentage of attached bacteria is significant because it could cause variability in transfer pathways, i.e. whether the transfer is direct or via protozoa. In view of the significance of bacterial production as a food source, future studies should determine the trophic fate(s) of bacterial production and its significance for food web structure and functioning in the creek ecosystems.

\section{Carbon fluxes}

BCD is a useful measure of cumulative carbon flux into bacteria. However, it is difficult to quantify, on the basis of BCP measurements, because of the uncertainty in bacterial growth yield. Earlier studies as- 
sumed growth yield to be $50 \%$ but a number of recent studies found much lower growth yields. Most literature values are within $50 \%$, generally 10 to $30 \%$, for a variety of coastal and oceanic environments. Linley \& Newell (1984) found that the growth yield of bacteria utilizing detritus decreases with increasing C:N. Since the $\mathrm{C}: \mathrm{N}$ of mangrove leaf litter was very high $(-80 ; \mathrm{S}$. King unpubl.), we expected the bacterial growth yield for our samples to be quite low. Bjørnsen (1986) found a growth yield of $30 \%$ for open-ocean bacteria. Tranvik \& Höfle (1987) and Tranvik (1988) found values of $26 \%$ in clear and humic lakes while Zweifel et al. (1993) found a range of 11 to $53 \%$ for coastal seawater samples. Smith et al. (1995) estimated yields of 9 to $17 \%$ for bacterial growth in a diatom bloom in a mesocosm. Generally, low values have been reported for growth on mangrove detritus. Benner \& Hodson (1985) found bacterial growth yield on mangrove leachates was 30\% for long-term incubations and, in another experiment, 2-fold higher for short-term incubations (Benner et al. 1986). However, mangrove particulate detritus was used at lower growth yields of 5 to $20 \%$ (Benner \& Hodson 1985) presumably due to structural complexity of the detritus. In view of this literature, we considered it appropriate to use, for bacteria utilizing mangrove particulates and leachates, a wide range of yield values, 10 to $30 \%$, thus covering the values found in most studies. This results in a 3-fold range of our $\mathrm{BCD}$ estimates, but sets reasonable upper and lower limits on the significance of bacteria in carbon fluxes.

Even our minimum BCD estimates show that the mangrove creek waters were persistently and highly net heterotrophic systems. At all stations and most sampling times, the net PP accounted for only a small fraction of BCD. Data integrated over the entire study period shows that even if all PP was used by bacteria, it would satisfy only 7 to $20 \%$ of the BCD; thus 80 to $93 \%$ of BCD would be met by reduced carbon from other sources. These percentages would be even higher if some of the phytoplankton production was used, as it most probably was, by organisms other than the heterotrophic bacteria. Assuming bacterial growth yield of 10 to $30 \%$, we can also calculate bacterial carbon respiration. Average respiration, integrated over the entire study period and for all sites, would be 824 to $2470 \mathrm{~g} \mathrm{C} \mathrm{m}^{-2} \mathrm{yr}^{-1}$ or 3 to 12 times the rate of $\mathrm{CO}_{2}$ fixation by the water-column phytoplankton. Our estimates of respiration were similar to respiration in the Hudson River estuary (Findlay et al. 1991, Howarth et al. 1992). We note, parenthetically and in concurrence with Jahnke \& Craven
(1995), that since respiration is the major fate of the organic matter taken up by bacteria, its direct measurement should be an important goal of the studies of bacteria-mediated carbon fluxes in aquatic ecosystems.

The mangrove trees probably supplied most of the BCD not met by the phytoplankton, through leaf litter, leaf leachates and root exudates. Additional organic matter could have been derived via the Indus River, however most upstream river water has been diverted for agricultural irrigation. Whether the river input of organic matter is indeed insignificant in the carbon budget of the mangrove creeks needs to be addressed in future studies. Benthic productivity and organic matter utilization were not examined and therefore their contributions to the water-column carbon dynamics are unknown. Kristensen et al. (1992) measured benthic metabolism in Isaro Creek and found that only $0.06 \mathrm{~g} \mathrm{C} \mathrm{m}^{-2} \mathrm{~d}^{-1}$ carbon was mineralized, via sulfate reduction, which was $<0.1 \%$ of our estimates of carbon mineralization in the water column.

\section{Controls on bacteria-mediated carbon flux}

There was a very tight coupling between bacterial production and removal. Specific growth rates gener-
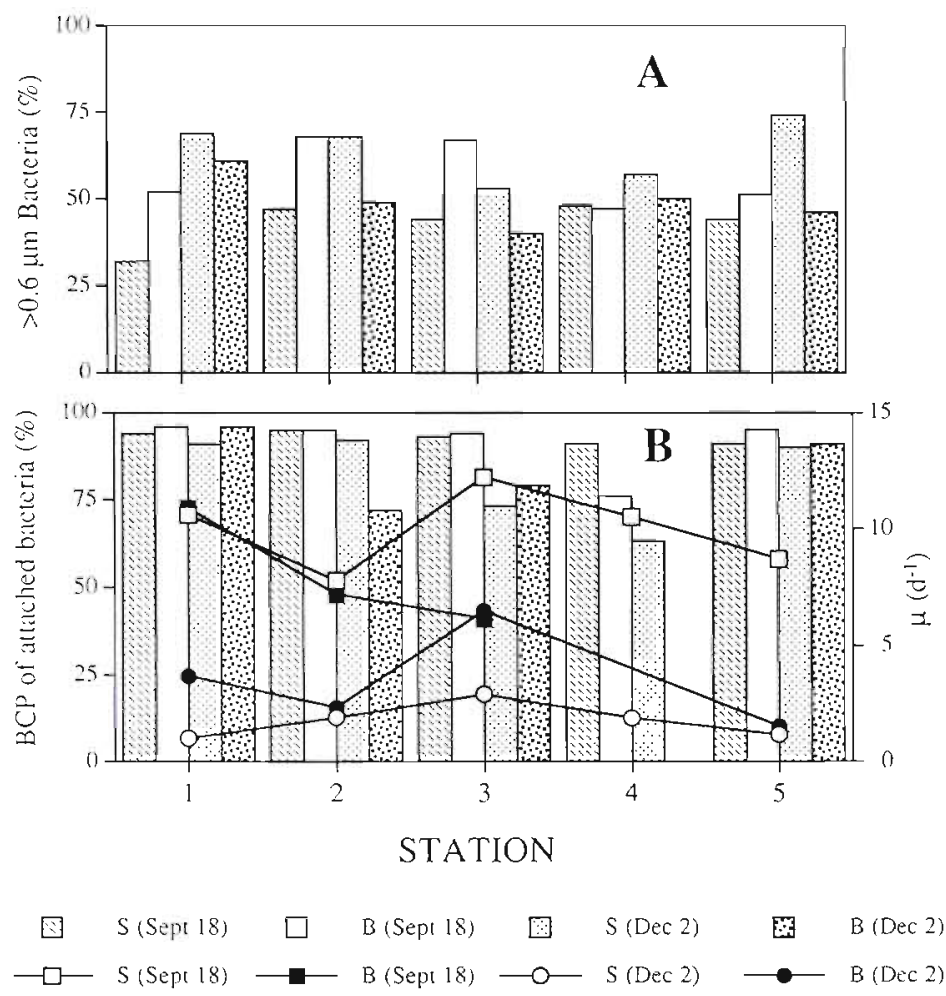

Fig. 8. (A) Percent bacterial abundance and (B) production (BCP, bars) and specific growth rate ( $\mu$, lines) of attached $(>0.6 \mu \mathrm{m}$ fraction) bacteria during 2 transects in Isaro Creek 


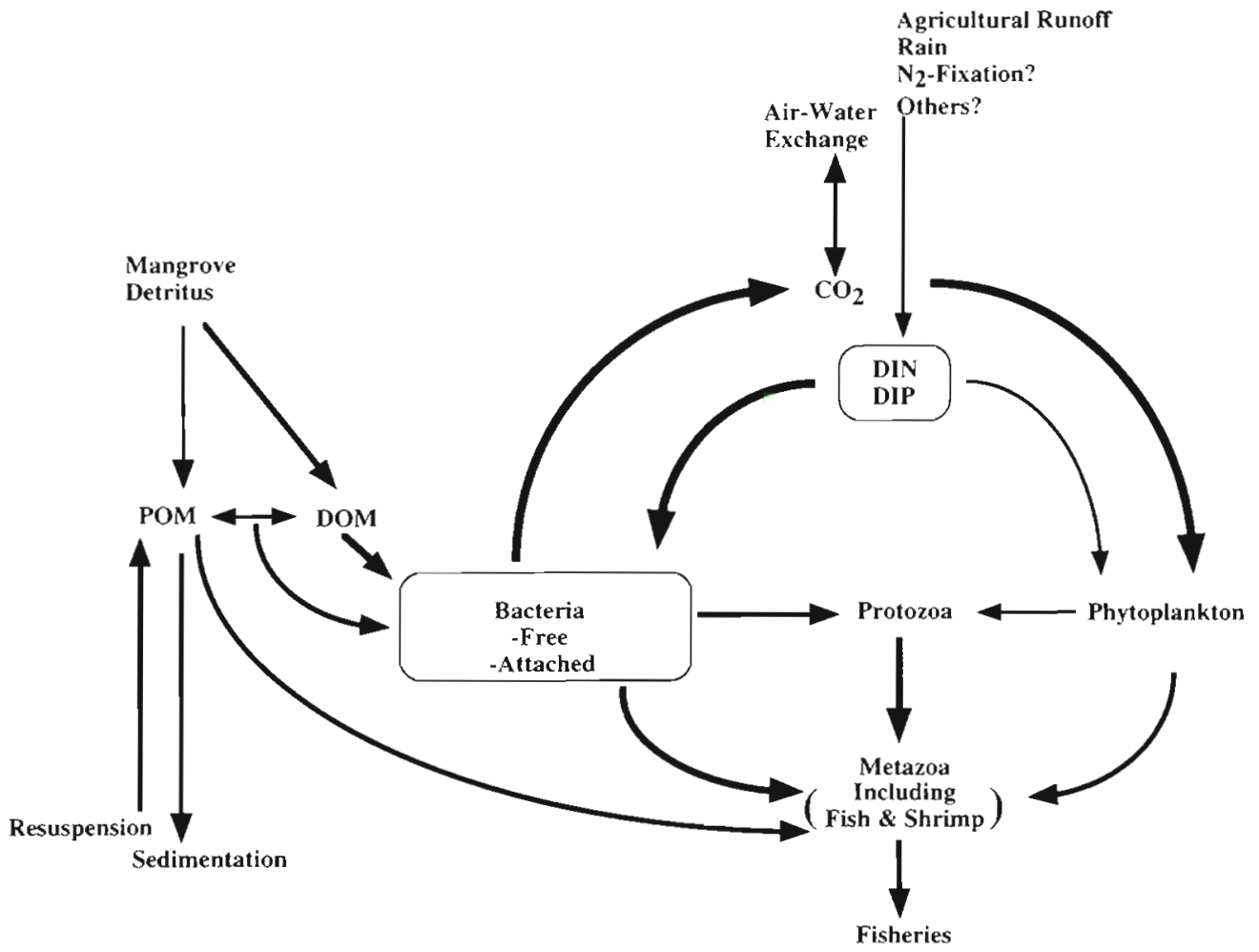

Fig. 9. Conceptual model of carbon fluxes in the Indus River delta mangrove tidal creeks. The model incorporated our finding of major carbon fluxes mediated by heterotrophic bacteria in the creek ecosystem. POM, DOM: particulate and dissolved organic matter; DIN, DIP: dissolved inorganic nitrogen and phosphorus

ally ranged from 1 to $7 \mathrm{~d}^{-1}$. Assemblage-average specific growth rate as high as $24 \mathrm{~d}^{-1}$ was found in one instance. Remarkably, despite such rapid growth, bacterial abundances generally remained within narrow ranges and at relatively modest levels of 1 to $4 \times$ $10^{6} \mathrm{ml}^{-1}$. These observations indicate a tight coupling in the carbon flow through the microbial loop.

Bacterial yield of the seawater cultures was on the order of 1.5 to $9.9 \times 10^{6}$ bacteria $\mathrm{ml}^{-1}$ (Table 2 ) or $\sim 30$ to $200 \mu \mathrm{g} \mathrm{C} \mathrm{I}^{-1}$ If we assume a carbon assimilation efficiency of $30 \%$ then the UDOC pool would be 97 to $656 \mu \mathrm{g} \mathrm{C} \mathrm{I}^{-1}$ (8 to $\left.55 \mu \mathrm{M}\right)$. As mentioned before, the bacterlal yield method may have underestimated the UDOC if significant bacterial mortality had occurred due to virus attack (Fuhrman \& Suttle 1993, Fuhrman \& Noble 1995). We cannot express these UDOC levels as a percentage of the total DOC since there are no DOC measurements in our study area. However, our UDOC values are comparable to those in the Savannah River site (USA), where the DOC concentration was 3 to $5 \mathrm{mg} \mathrm{I}^{-1}$, and in the Okefenokee Swamp (USA), where the DOC concentration was 32 to $39 \mathrm{mg} \mathrm{l}^{-1}$ (Moran \& Hodson 1990). In order to sustain the measured BCD $\left(643 \pm 671 \mu \mathrm{g} \mathrm{C}^{-1} \mathrm{~d}^{-1}\right)$ the UDOC pool would have to turn over in less than a day to a few days. If the UDOC pool was significantly underestimated due to viral mortality of bacteria then the actual turnover times would be longer than we estimate. Consistent with rapid UDOC turnover, we found that the ${ }^{14} \mathrm{C}$-leucine added at $5 \mathrm{nM}$ had an assimilation turnover time of $\sim 5 \mathrm{~h}$. Assuming a $70 \%$ assimilation efficiency for leucine utilization (Carlucci et al. 1986) the leucine pool turnover time due to assimilation + respiration would be $-3.5 \mathrm{~h}$. Fuhrman (1987) found comparable turnover times for amino acids in the Long Island Sound (USA) waters. Since amino acids are amongst the most readily utilizable UDOC components, the total UDOC pool turnover time would be longer than $3.5 \mathrm{~h}$ and this is consistent with our estimates of UDOC turnover times of $<1 \mathrm{~d}$ to a few days.

Limited data suggest that bacterial production in our study area may have been limited by the supply of energy rather than $\mathrm{N}$ or $\mathrm{P}$. Enrichment of creek water samples with $10 \mu \mathrm{M}$ ammonium or phosphate did not significantly enhance bacterial protein production rate (not shown). This is consistent with the observation that ammonium and phosphate concentrations in the water column were generally quite high, greater than 1 HM (Harrison et al. 1997). It would thus appear that the introduction of $\mathrm{N}$ and $\mathrm{P}$ into the particulate phase 
via bacterial growth was limited by the supply of energy, much of which was derived from mangrove carbon.

\section{A conceptual model of material and energy flow}

Fig. 9 highlights the significance of the input of mangrove detritus as providing the majority of the reduced carbon needed to channel $\mathrm{N}$ and $\mathrm{P}$ from the dissolved phase into the particulate phase, in the form of bacterial biomass, where it becomes available to the protozoa and metazoa. The C:N ratio of natural assemblages of marine bacteria has been reported to be 3.8 (Lee \& Fuhrman 1987). Using averáge bacterial carbon production for the 3 creeks, we estimated that $\mathrm{N}$ assimilation into bacteria in the creek water columns would be on the order of $100 \mathrm{~g} \mathrm{~N} \mathrm{~m}^{-2} \mathrm{yr}^{-1}$. What fraction of the reduced carbon and assimilated $\mathrm{N}$ is passed on to the higher trophic levels will depend partly on the types of organisms feeding on bacteria and their abilities to digest and assimilate bacterial biomass. Further, the utilization of the bacterial biomass will depend on whether bacteria are attached to the particles or whether they are free (discussed above). The focus of the conceptual model for the mangrove creeks in Fig. 9 is that bacteria are the main conduit for channeling $\mathrm{N}$ and $\mathrm{P}$ into the particle-based food web leading up to the higher trophic level animals, including the shrimp and the fish of commercial importance. The primary producers, being light limited, play a lesser role in introducing $\mathrm{N}$ and $\mathrm{P}$ into the biomass. However, the energy needed to channel $\mathrm{N}$ into the microbial biomass appears to be derived largely from the mangrove productivity. This highly simplified model predicts that the destruction of the mangrove forests, now occurring, could have a major impact on the ecosystem structure and functioning as well as the production of economically important fish and shrimp in the Indus delta mangroves.

Acknowledgements. This study was funded by a grant from the U.S. National Science Foundation \#INT-8818807 to S.I.A. We are grateful to Niaz Rizvi for cooperation and valuable suggestions. We also thank David C. Smith for stımulating discussion, Grieg Steward for TEM counts of viruses and Wendy Dustman for helpful suggestions. N.B. was supported by National Science Foundation grant DEB 9222479 to R. E. Hodson during manuscript preparation. F.A. was supported by National Science Foundation grant OPP 95-30851 during manuscript preparation

\section{LITERATURE CITED}

Ahmed SI (1992a) Coping with excess salt in their growth environments: osmoregulation and other survival strategies deployed by the mangroves. Pak J Mar Sci 1:73-86
Ahmed Sl (1992b) The marked reduction of the Indus River flow downstream from the Kotri Barrage: can the mangrove ecosystems of Pakistan survive in the resulting hypersaline environment? Pak J Mar Sci 1:145-153

Alongi DM (1988) Bacterial productivity and microbial biomass in tropical mangrove sediments. Microb Ecol 15: $59-79$

Alongi DM (1992) Vertical profiles of bacterial abundance, productivity and growth rates in coastal sediment of the central Great Barrier Reef lagoon. Mar Biol 112:657-663

Ammerman JW, Fuhrman JA, Hagström $\AA$, Azam F (1984) Bacterioplankton growth in seawater I. Growth kinetics and cellular characteristics in seawater cultures. Mar Ecol Prog Ser 18:31-39

Azam F, Fenchel T, Field JG, Gray JS, Meyer-Reil LA, Thingstad $F$ (1983) The ecological role of water-column microbes in the sea. Mar Ecol Prog Ser 10:257-263

Azam F, Hodson RE (1981) Multiphasic kinetics for D-glucose uptake by assemblages of natural marine bacteria. Mar Ecol Prog Ser 6:213-222

Benner R, Hodson RE (1985) Microbial degradation of the leachable and lignocellulosic components of leaves and wood from Rhizophora mangle in a tropical mangrove swamp. Mar Ecol Prog Ser 23:221-230

Benner R, Peele ER, Hodson RE (1986) Microbial utilization of dissolved organic matter from leaves of the red mangrove, Rhizophora mangle, in the fresh creek estuary, Bahamas. Estuar Coast Shelf Sci 23:607-619

Bent EJ, Goulder R (1981) Planktonic bacteria in the Humber estuary; seasonal variation in population density and heterotrophic activity. Mar Biol 62:35-45

Bjarnsen PK (1986) Bacterioplankton growth yield in continuous seawater cultures. Mar Ecol Prog Ser 30:191-196

Bjornsen PK, Kupannen J (1991) Determination of bacterioplankton biomass, net production, and growth efficiency in the Southern Ocean. Mar Ecol Prog Ser 71:185-194

Boto KG, Alongi DM, Nott ALJ (1989) Dissolved organic carbon-bacteria interactions at sediment-water interface in a tropical mangrove system. Mar Ecol Prog Ser 51:243-251

Carlucci AF, Craven DB, Robertson KJ, Henrichs SM (1986) Microheterotrophic utilization of dissolved free amino acids in depth profiles of southern California borderland basin waters. Oceanol Acta 9:89-96

Cho BC, Azam F (1990) Biogeochemical significance of bacterial biomass in the ocean's euphotic zone. Mar Ecol Prog Ser 63:253-259

Crump BC, Baross JA (1996) Particle-attached bacteria and heterotrophic plankton associated with the Columbia River estuarine turbidity maxima. Mar Ecol Prog Ser 138: 265-273

Ducklow HW, Hill SM, Gardner WD (1985) Bacterial growth and the decomposition of particulate organic carbon collected in sediment traps. Cont Shelf Res 4:445-464

Fagerbakke KM, Heldal M, Norland S (1996) Content of carbon, nitrogen, oxygen, sulfur and phosphorus in native aquatic and cultured bacteria. Aquat Microb Ecol 10: $15-27$

Findlay S, Pace ML, Lints D, Cole JJ, Caraco NF, Peierls B (1991) Weak coupling of bacterial and algal production in a heterotrophic ecosystem: the Hudson River estuary. Limnol Oceanogr 36:268-278

Fuhrman JA (1987) Close coupling between release and uptake of dissolved free amino acids in seawater studied by an isotope dilution approach. Mar Ecol Prog Ser 37:45-52

Fuhrman JA, Noble RT (1995) Viruses and protists cause similar bacterial mortality in coastal seawater Limnol Oceanogr 40:1236-1242 
Fuhrman JA, Suttle AC (1993) Viruses in marine planktonic systems. Oceanography 6:51-63

Harris GP (1986) Phytoplankton ecology: structure, function and fluctuation. Chapman and Hall, New York

Harrison PJ, Khan N, Yin K, Saleem M, Bano N, Nisa M, Ahmed SI, Rizvi N, Azam F (1997) Nutrient and phytoplankton dynamics in two mangrove tidal creeks of the Indus River delta. Mar Ecol Prog Ser 157:13-19

Harrison PJ, Snedaker SC, Ahmed SI, Azam F (1994) Primary producers of the arid climate mangrove ecosystem of the Indus River delta, Pakistan: an overview. Trop Ecol 35: $155-184$

Healey MJ, Moll RA, Diallo CO (1988) Abundance and distribution of bacterioplankton in the Gambia River, West Africa. Microb Ecol 16:291-310

Hobbie JE, Daley RJ, Jasper S (1977) Use of Nuclepore filters for counting bacteria by fluorescence microscopy. Appl Environ Microbiol 33:1225-1228

Howarth RW, Marino R, Garritt R, Sherman D (1992) Ecosystem respiration and organic carbon processing in a large, tidally influenced river: the Hudson River Biogeochemistry 16:83-102

Jahnke RA, Craven DB (1995) Quantifying the role of heterotrophic bacteria in the carbon cycle: a need for respiration rate measurements. Limnol Oceanogr 40:436-441

Kirchman DL, K'Nees E, Hodson RE (1985) Leucine incorporation and its potential as a measure of protein synthesis by bacteria in natural aquatic systems. Appl Environ Microbiol 49:599-607

Kristensen E, Devol AH, Ahmed SI, Saleem M (1992) Preliminary study of benthic metabolism and sulfate reduction in a mangrove swamp of the Indus delta, Pakistan. Mar Ecol Prog Ser 90:287-297

Lawrence SG, Ahmad A, Azam F (1993) Fate of particlebound bacteria ingested by Calanus pacificus. Mar Ecol Prog Ser 97:299-307

Lee S, Fuhrman JA (1987) Relationships between biovolume and biomass of naturally derived marine bacterioplankton. Appl Environ Microbiol 53:1298-1.303

Linley EAS, Newell RC (1984) Estimates of bacterial growth yields based on plant detritus. Bull Mar Sci 35 $409-425$

Editorial responsibility: Jed Fuhrman (Contributing Editor), Los Angeles, California, USA
Lugo AE Snedaker SC (1974) The ecology of mangroves. Annu Rev Ecol Syst 5:39-64

Mann KH (1972) Macrophyte production and detritus food chains in coastal waters. Mem Ist Ital Idrobiol 29 (Suppl) 353-383

Moran MA, Hodson RE (1990) Bacterial production on humic and non humic components of dissolved organic carbon Limnol Oceanogr 35:1744-1756

Parsons TR, Maita Y, Lalli CM (1984) A manual of chemical and biological methods for seawater analysis. Pergamon Press, New York

Riemann B, Azam F (1992) Measurements of bacterial protein production in eutrophic aquatic environments by means of leucine incorporation. Mar Microb Food Webs 6:91-105

Simon M, Azam F (1989) Protein content and protein synthesis rates of planktonic marine bacteria. Mar Ecol Prog Ser $51: 201-213$

Smith DC, Azam F (1992) A simple, economical method for measuring bacterial protein synthesis rates in seawater using ${ }^{3} \mathrm{H}$-leucine. Mar Microb Food Webs 6:107-114

Smith DC, Steward GF, Long RA, Azam F (1995) Bacterial mediation of carbon fluxes during a diatom bloom in a mesocosm. Deep Sea Res 42:75-97

Snedaker SC (1984) Mangroves: a summary of knowledge with emphasis on Pakistan. In: Haq BU, Milliman JD (eds) Marine geology and oceanography of Arabian Sea and coastal Pakistan. Van Nostrand Reinhold Co, New York, p 255-262

Steemann Nielsen E (1952) The use of radioactive carbon $\left({ }^{14} \mathrm{C}\right)$ for measuring organic production in the sea. $\mathrm{J}$ Cons Perm Int Explor Mer 18:117-140

Tranvik LJ (1988) Availability of dissolved organic carbon for planktonic bacteria in oligotrophic lakes of different humic content. Microb Ecol 16:311-322

Tranvik LJ, Höfle MG (1987) Bacterial growth in mixed cultures on dissolved organic carbon from humic and clear waters. Appl Environ Microbiol 53:482-488

Wright RT, Hobbie JE (1965) The uptake of organic solutes in lake water. Limnol Oceanogr 10:22-28

Zweifel LU, Norrman B. Hagström $\AA$ (1993) Consumption of dissolved organic carbon by marine bacteria and demand for inorganic nutrients. Mar Ecol Prog Ser 101:23-32

Submitted: October 10, 1996; Accepted: May 28, 1997 Proofs received from author(s): September 16, 1997 